\title{
Cross-Border Co-Operation Euro-Regions at the European Union Eastern Frontier within the Context of Romania's Accession to the Schengen Area
}

\author{
Săgeată RaduA \\ Received: June 2011 | Revised: August 2011 | Accepted: November 2011
}

\begin{abstract}
The paper analyses a sector of the EU and NATO eastern border, basically, the frontier-line between Romania on the one hand, and the Republic of Moldova and Ukraine, on the other, a sector supposed to become also a Schengen border. The ethnical structure of the population living close to the frontier-area, the cohesion and functionality of the local and regional settlements systems, as well as the cross-border co-operation euro-regions are also discussed. Both banks of the Pruth River are heavily populated, doublet settlements acting as relays interconnecting the two settlement systems formed within the framework of a common historical background. The ethnical unity is a major binder of the territories lying on either side of the Pruth River and constituting the three Euro-regions. Romania's strivings to integrate into the European and Euro-Atlantic co-operation structures makes it necessary to secure its eastern border and control migration fluxes in this part of the Continent. The Pruth River becomes an axis of integration due to the continuity of the ethnical-linguistic element, as well as to the density and continuity of settlement on either bank; on the other hand, it also becomes an axis of fragmentation given its future role of relatively stable NATO and EU frontier-line, fact that imposes specific cross-border co-operation.
\end{abstract}

Key-words: EU eastern frontier, cross-border co-operation, human settlements, ethnic unity, Pruth Basin

\begin{abstract}
Aim and Methods
The present analysis is aimed at highlighting the importance attached by the European Union to Romania's Eastern border and the challenges posed by its role of EU Eastern frontier and of being the national border of a homogeneous ethnical bloc. What is required in the first case is to best secure it in order to efficiently control human and material fluxes coming from the former Soviet space, a basic prerequisite for Romania's accession to the Schengen space; in the second case one must ensure a certain permeability imposed by the unity of the Romanian ethnical bloc on either side of the Pruth River, and by traditional historical relations established in the course of time at the level of the settlement system. A special importance to this effect have the three cross-border co-operation euro-regions formed within the upper Pruth Basin: the Upper Pruth, the Siret-Pruth-Dniester and the Lower Danube.

Proceeding from the European models of crossborder co-operation, and from differences exist-
\end{abstract}

ing between the East and the West of the Continent in matters of this type of co-operation, the typology of cross-border co-operation euro-regions is based on four criteria: the factors determining the formation of euro-regions (cross-border urban agglomerations, doublet settlements, ethnical cohesion, cross-border communication axes, joint exploitation of marine and lake basins, or natural homogeneous potential); the economic development level of the border areas forming these euro-regions (symmetrical or asymmetrical euro-regions); the number of states that form the euro-regions or the continuity of the ethnical element.

The cross-border co-operation framework at Romania's Eastern frontier relies on doublet settlements existing on either side of the Pruth River and the unity of the Romanian ethnical element (with the exception of some Upper Pruth and Lower Danube areas that have a majority, or compact, Ukrainian population. In order to illustrate the importance of doublets in the structure

A Institute of Geography, Romanian Academy, Bucharest, e-mail: radusageata@yahoo.com 
of euro-regions, a theoretical model illustrating the German-Polish frontier (on the Oder-Neisse) has been elaborated, and detailed out for the Rep. of Moldova-Romania frontier (on the Pruth), both border areas being assymmetrical in terms of economic and social development level. Furthermore, the work dwells on the historical context in which the frontier-line along the Pruth was traced, the ethnical situation, the settlement network and the extent of border permeability.

The methods used were both deductive and inductive.

\section{Backgrounds}

The Schengen Aquis is part and parcel of the EU Community Aquis thoroughly accepted by Romania on April 25, 2005 on the occasion of its signing the EU Accession Treaty. As of January I, 2007 this country has become a Community member with full rights. On June 28, 2007, Romania sent the Schengen Evaluation Working Group the Declaration of Preparedness in three domains: protection of personal data, police co-operation and vizas. On July 15, 2oro Romania's Schengen Evaluation Raport in matters of terrestrial borders was approved. The date for the country's accession to the Schengen Area was set for 2012.

In view of the above, analyzing the particularities of Romania's eastern border (basically the future Schengen Area frontier), the euro-regions and the existing cross-border co-operation framework, has acquired special importance.

\section{Cross-Border Co-operation Euro- regions in Western and Eastern Europe}

Cross-border co-operation euro-regions have been established in Western Europe in the wake of intense cross-border active collaboration. The main factors underlying it are cross-border urban polarization nuclei and the configuration of the respective state frontiers (Becart \& Brodaty, I998). A first such euro-region (Regio Basilensis) was set up in I963 and officially recognized only in I976. It was based on the cross-border polarisation area (Switzerland-France-Germany) of the town of Basel. The fast pace of industrial development in the post-war period and the liberalisation of customs have contributed to the swift growth of this urban agglomeration which expanded beyond the bounds of the national territory. This situation was the outcome of the economic relations going on in time, as well as of the relatively high level of industrialisation and urbanisation of cross-border regions in Switzerland, France and Germany.

Another euro-region, Regio Genevensis, between Switzerland and France, is based on the polariza- tion area of Geneva. Because in the surroundings of Geneva there was little housing space and prices were soaring, people working in the cross-border area would build dwelling-houses in France, close to the Swiss frontier, while French border people would come and work in Geneva and its surroundings where they got higher salaries. As a result, urbanisation enlarging, the French crossborder area became actually kind of Geneva's hinterland. Between Switzerland and Italy lies Regio Insubrica, an area extending from the Italianspeaking Swiss canton (district) of Tessin and the metropolitan area of Milan in Italy. The populations' linguistic unity is only too obvious. Many parts of the Swiss industry were moved close to the Italian border to profit from cheaper Italian labour. However, when the well-structured performant industry of the Italian provinces of Como, Varese and Lecco, one of the best developed areas in Italy, decided to close down, dismantle and reconvert their industrial units (in the latter half of the I970s), the redundant workforce was absorbed by the Tessin canton job market, smoothing down the otherwise high social costs. So, the cross-border relation proved mutually beneficial (Wackermann, I99I).

East of the former Iron Curtain, cross-border euro-regions began mushrooming only after 1990 . Extending from the Baltic Sea to the Adriatic Sea, they inevitably show distinctively different features in terms of structure, characteristics and functionality (Engel \& Rogers, 1996).

Noteworthy, cross-border co-operation in Central and Eastern Europe did not develop on empty ground, because it had an institutionalized past (the COMECON), a community of interests established four decades earlier (I949-I989), long before the fall of the Iron Curtain. Within this framework, they initiated many joint projects of territorial planning and unitary development of the communications infrastructure. However, since the legislative framework was restrictive and subordinated to momentous ideological orientations, contacts went on rather at a lower level, being resumed and enhanced only after the reunification of Germany, perceived to be the first step towards a reunified Europe (Gonin, 1994). Territorial solidarity, brutally severed after I945, was being resumed, cross-border fluxes would intensify, and frontiers seemed no longer a barrier in the way of co-operation, despite extremely different political-administrative entities, whose recent history rather estranged than approached them. The political, economic, social and cultural impact of these new territorial solidarities, manifest far and above frontiers and historical antagonisms, targets a lot of major aspects, the stake being the EU integration of the new, formerly communist democracies. 
What has emerged are some oversized territorial structures (the Alpine-Adria Community, the Carpathian Euro-region, the Danube-Criş-MureşTisza Euro-region, the Bug Euro-region, etc.) which fall short of many requirements because they have few elements of complementary or direct exchange in common. Moreover, unlike their West-European counterparts, the states forming the East-European euro-regions are less economically developed and far more heterogeneous, many of these cross-border co-operation structures being grafted on the former Iron Curtain (it is especially the case of the 8 euro-regions along the German-Polish and German Czech frontiers). The frontier areas of Poland, the Czech Republic, Slovakia and Hungary are actually dotted with euro-regions (Deică, 1997).

The euro-regions set up after 1990 are macroterritorial structures, formed by the aggregation of macro-territorial administrative units, usually extending along the big Pan-European traffic corridors. Typical examples are the North Euroregion based on the co-operation between Belgium, the French region Nord - Pas de Calais and the English County of Kent; the Trans-Pyreneean Mediterraneean Euro-region, which includes Catalonia, Languedoc-Rousillon and Midi Pyrénées, or the Saar-Lor-Lux Euro-region (Saar-LorraineLuxembourg) (Seguy, I998).

It follows that cross-border co-operation euro-regions are territorial structures created with the aim of intensifying inter-regional and crossborder co-operation in order to achieve a coherent space for economic, scientific, social and cultural development.

Some proposals for a classification of these euro-regions are put forward herein:

I. Factors determining the formation of euro-regions:

- Cross-border urban agglomerations: Regio Basilensis (Basel), Regio Genevensis (Geneva), Regio Insubrica (Milan), etc.;

- Town doublets: at the German-Polish, German-Czech frontiers, etc.;

- Unitary ethnic structure: the Carpathian Euro-region, the Upper-Pruth Euro-region, the Lower Danube Euro-region, etc.;

- Cross-border communication axes: the North Euro-region, Saar-Lor-Lux Euro-region, etc.;

- Joint exploitation of marine and lake basins: Pomerania Euro-region, etc.;

- Natural homogeneous potential: Barents Euro-region, etc.;

2. The extent to which component cross-border regions have a comparable economic and social development:

- Symmetrical euro-regions: cross-border euro-regions of a relatively similar technical- urbanistic development (euro-regions in the EU space, or cross-border euro-regions of external EU states);

- Asymmetric euro-regions formed by the association of cross-border regions with a distinct development level: the euro-regions at the German-Polish, German-Czech frontier, etc.;

3. The number of states that form the euro-regions:

- Euro-regions formed at the frontier of two states (through the extension of two crossborder regions): Bihor-Hajdu Bihar Euro-region, Giurgiu-Ruse Euro-region, etc.;

- Euro-regions formed at the frontier of three states: the Danube-Mureş-Tisza Euro-region, the Upper-Pruth and the Lower Danube Euro-regions, etc.;

- Euro-regions formed at the frontier of four or more states (macro-euro-regions): the Carpathian Euro-region, Pomerania Euroregion, etc.;

4. The continuity of the ethnical element:

- Ethnically homogeneous euro-regions;

- Ethnically heterogeneous euro-regions.

The division created by the hydrographic networks has allowed individualizing some nuclei that gather transversal fluxes in the situation in which local topographic conditions have allowed it, e.g. fording rivers has led to the concentration of population on both watersides, hence settlement doublets emerged playing a local or even regional role.

In time, the cross-border nuclei of demographic concentration act as embryos of euro-regions formation, once the small border traffic gets momentum at macro-territorial level based on the relations existing within the settlements systems of the limitrophe administrative territorial units (Figure I a,b,c).

\section{The impact of border tracing on the settlement system}

For a lapse of almost fifty years, political decisions turned the River Pruth into an axis of discontinuity, into a hardly penetrable frontier (especially over the 1950-1960 interval), severing normal relations between the settlement systems of Bessarabia, and the rest of Moldavia which remained part of the Romania state. laşi and Galaţi became border towns. As the frontier was practically closed, the influence zones of the two towns kept shrinking considerably, and their capacity to polarize the settlement system had to be redimensioned. On the other hand, since Chişinău acquired a hypertrophic character compared to the second largest town of historical Bessarabia, 

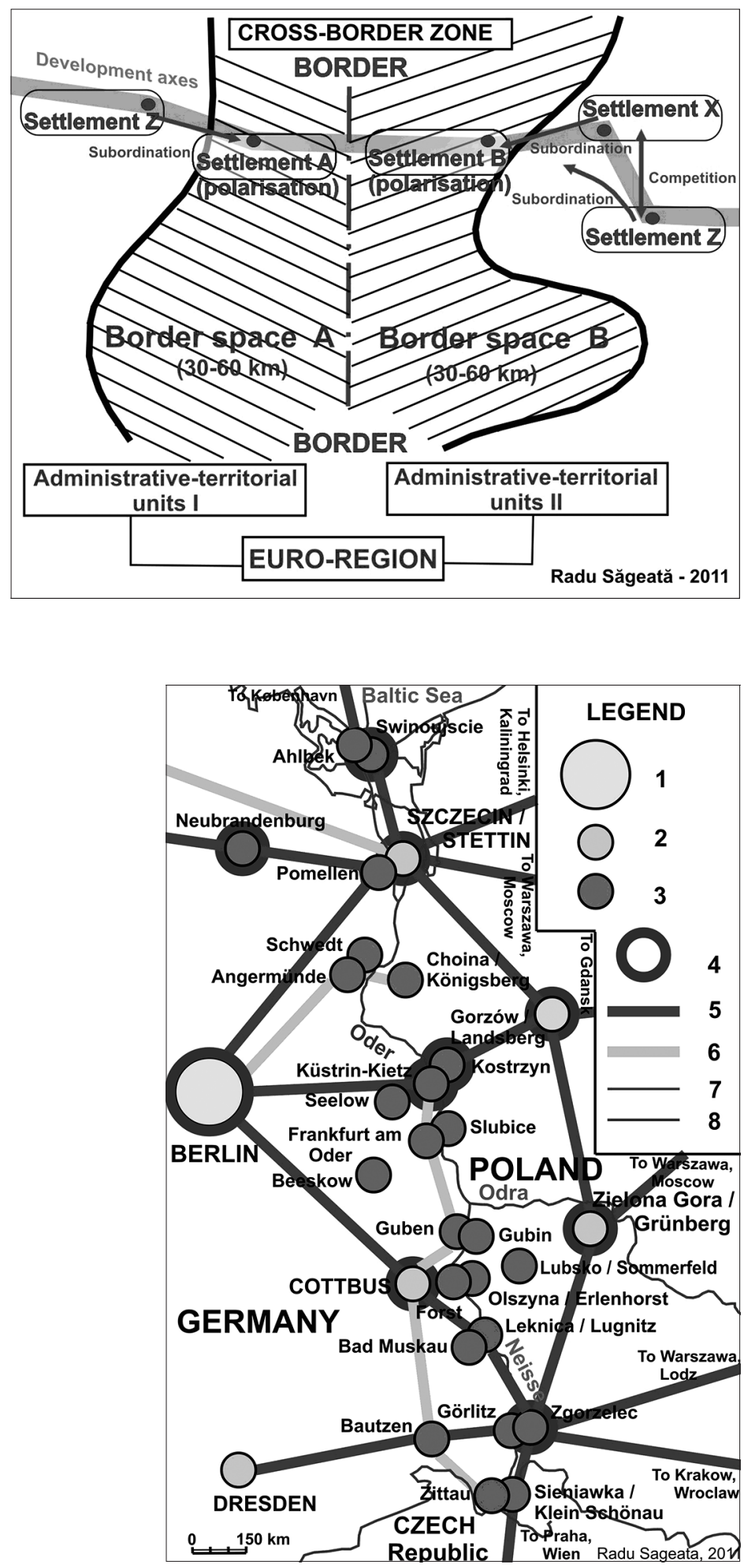

Figure 1a [above]. The Role of the Human Settlements in the Structure of Euro-regions. Theoretical Aspects

Figure 1b [below]. Doublet settlements and cross-border development axes along German-Polish frontier [Oder-Neisse] [Sources: Bundesanstalt für Landesplanning und Raumlorschung, Bonn; Gaunard, 1998]

1. European polarisation nuclei, 2. Regional polarisation nuclei, 3. Local polarisation nuclei, 4. Peri-urban development areas, 5. Inter-regional development axes, 6. Regional development axes, 7. Terrestrial frontiers, 8. Water arteries / shores.

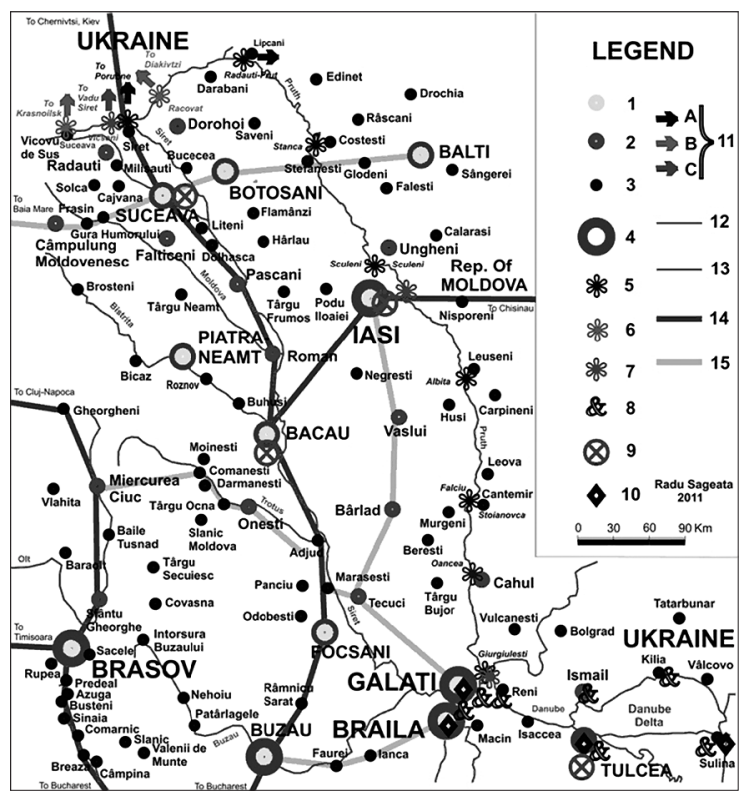

Figure 1c. Doublet settlements and cross-border development axes along the Romanian - Republic of Moldova frontier [Pruth]

1. Regional polarisation nuclei, 2. Local polarisation nuclei,

3. Towns, 4. Peri-urban development areas, 5. International road customs points, 6. Small border traffic road customs points, 7. International railway customs points, 8. River ports, 9. Airports, 10. Free zones, 11. Connections: A. International road traffic, B. Small border road traffic, C. International railway traffic, 12. Borderlines, 13. Water arteries / shores, 14. Inter-regional development axes, 15. Regional development axes.

namely Cetatea Albă (1930), the main functional disorders were being felt on the upper level of the urban hierarchy, traditional relations of Chişinău with Iaşi and Galaţi, the two towns that had macro-territorial polarizing functions for the Moldavian space, breaking down. Moreover these functions were being amplified by political decisions: on November 24, I94O I. V. Stalin decided that the counties of Hotin, Ismail and Cetatea Albă should be severed from historical Bessarabia and included, together with the North Bukowina counties of Cernăuţi and Storojineţ (in the northern part of Rădăuţi Country - Romania) into the Ukrainian regions of Cernăuţi and Odessa (Simileanu \& Săgeată, 2009).

The loss of half of Bukowina's northern part disorganized its settlement system. Out of a total area of $10,442 \mathrm{~km}^{2}$ representing the Great Dukedom of Bukowina (integrated into the Romania state on November 28, I9I8), what was left after the Second Soviet Ultimatum (the Note of June 28, I940) were only $5,200 \mathrm{~km}^{2}$ (Rus, I997); from eleven counties (Câmpulung, Cernăuţi, Coţmani, Gura Humorului, Rădăuţi, Siret, Storojneţ, Suceava, Văşcăuţi, Vijniţa and Zastavna) what remained in 1926 were only five (Câmpulung, Cernăuţi, Rădăuţi, Storojineţ and Suceava); and only Câmpulung, Suceava and the southern part of Rădăuţi 
Country were maintained within the borders of Romania (Figure 2).

The polarising core - Cernăuţi - of the macro-territorial whole was no longer in Romania, while Bukowina's urban system was divided into two distinct parts: one Ukrainian, centred around Cernăuţi, which had now a much smaller influence zone, and the other Romanian, itself marked by fragmentation because the towns of Suceava, Rădăuţi and Câmpulung Moldovenesc, which had a rather similar demographic, economic and social potential, were competing among themselves. Being dismantled and included (I950) into a macroterritorial administrative structure (Suceava Region), which encompassed also large areas from Moldavia's territory, the characteristic identity of Bukowina was much diminished; besides, deepgoing changes occurred in the functional relations between human settlements the moment Suceava town acquired a major co-ordinating role, while Rădăuţi, Câmpulung and Fălticeni remained hierarchically subordinated (Kalmustskaia, 2004).

At micro-territorial level, the spontaneous flows of people and materials between the local communities situated on either side of the Pruth River declined considerably, being channeled instead along some main directions: laşi-Ungheni and Vicşani (rail traffic), Siret-Porubne and AlbiţaLeuşeni (road traffic).

In the early I990s, political opening was immediately accompanied by openness in inter-human relations. Among the actions of restitutio in integrum, were the so-called "flower bridges" between the Romanians living on either side of the River, which reunited families and destinies broken in June 1940. Also the post-revolutionary political class of Romania and of the young state of Moldova, viewed it as a positive move. The existence of settlement doublets led to the opening of customs points, regular bus services and exchanges of goods and people. These were the first actions leading to the formation of euro-regions. However, economic difficulties, the Transnistrian war, the secessionist tendencies of the Gagautzi population, the fear of part of the Rusophone population lest a unification with Romania might take place had gradually stopped this momentous enthusiasm. Organized criminality, illegal migrations favoured by an inadequate customs control infrastructure, have imposed restrictive measures on the cross-border traffic (Ilieş, 2003). These measures had to be tightened after 1995, when Romania applied for EU membership, and especially after January I, 2007, when it was admitted to the Organisation and the Pruth River became the European Union's external frontier.

In these conditions, the Romanian-Romanian cross-border area of the Pruth hydrographic ba-

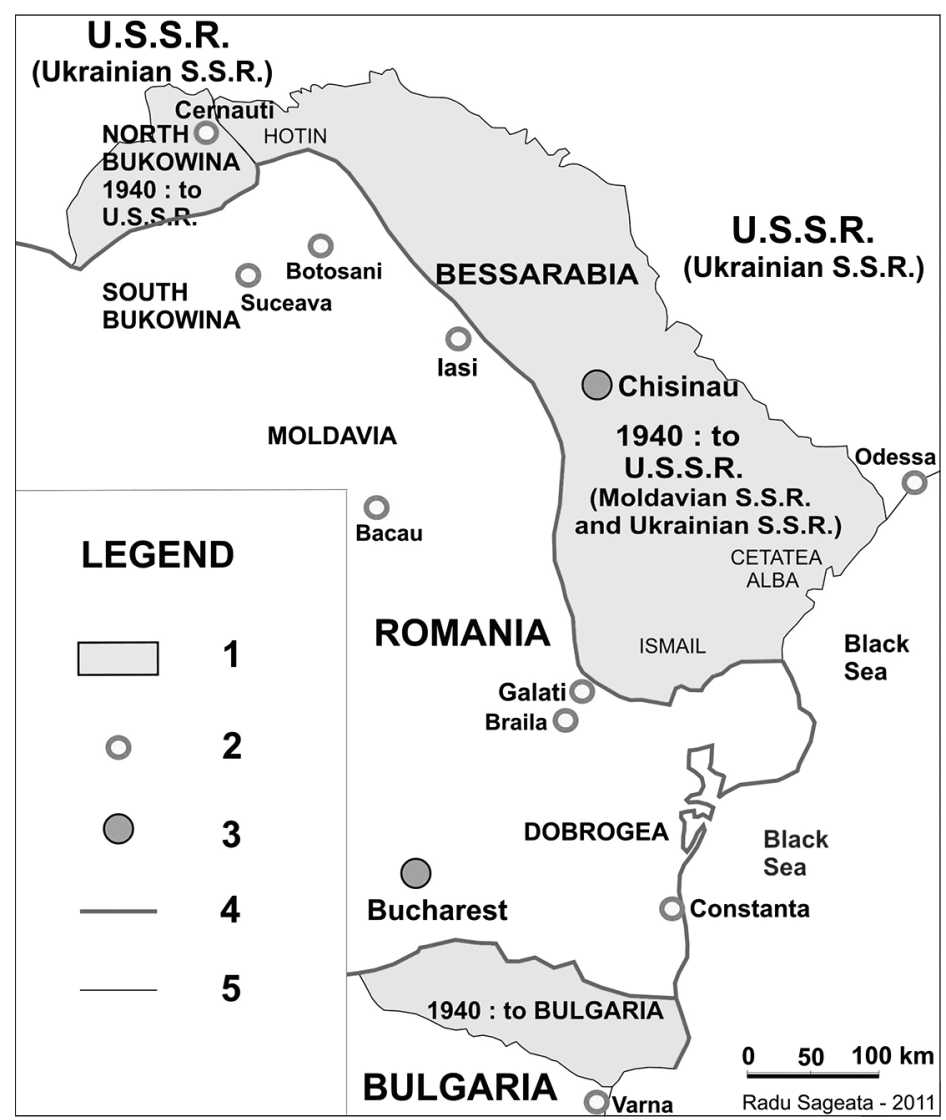

Figure 2. Evolution of Romania's Eastern Border after 1940 1. Romanian lands included into the territories of other states in 1940, 2. Regional polarization nuclei, 3. National Capital-city, 4. Current borderlines, 5. Dismantled borderlines

sin has suffered significant mutations. Whereas in the former Yugoslav space, the "island" left outside the European Union tends to shrink, Slovenia having been admitted as EU member in 2004 , and the applications filed by Croatia, the Republic of Macedonia (FYROM) and Serbia accepted, the Pruth appears to act increasingly more as a relatively stable frontier of the Union, having to cope with new challenges raised by the ambivalence between necessary restrictions to create a reliable filter and prevent cross-border fluxes to penetrate its eastern frontier, and the high degree of ethnic homogeneity of the Romanians living on both banks of the River. Therefore, intensifying crossborder co-operation is an imperative necessity.

\section{Ethnic homogeneity at EU's eastern frontier}

Throughout its course on Romanian territory (7I6 km of the River's $953 \mathrm{~km}$ ) the Pruth constitutes a border. From its springs in the Forested Carpathians (Ukraine), the River enters Romania somewhere in front of Oroftiana settlement (Botoşani County), forming the Romanian-Ukrainian frontier (cca. $36 \mathrm{~km}$ ). But on either side of the River there exists a strong ethnically Romanian homo- 
geneous area. This assertion is based on the historical past, on the 200I Ukrainian census and on the toponymic reality which, for all the historical vicissitudes, is in place unaltered. Herţa Land, an old Romanian country, was encompassed into the Soviet Union on June 29, I940 after a second ultimatum note was given by the Soviets, on the night of June $27 / 28$, I940. What should be remembered is that this territory was mentioned neither in the Ribbentrop-Molotov Treaty nor in the I940 Soviet Ultimatum (Lupan, quoted by Stamate, 1997). In the second half of the $18^{\text {th }}$ century, Herţa had become an administrative county-seat in Moldavia, Herţa Land (cca. $400 \mathrm{~km}^{2}$ ) having been united with Dorohoi Land in 1834 .

Today, Herţa District, integrated into the administrative region of Cernăuţi, represents a compact ethnic Romanian area, containing only a small village of Ukrainians (Ukrainian Marmoniţa) (Popescu, 2004). In I989, the population of Herţa District numbered 29,6II inhabitants (Soviet census data) out of which 27,517 (92.93\%) were Romanian ethnics, 23,539 of them declaring themselves Romanians and 3,978 Moldavians, the latter living in the villages of Ostriţa, Tureni and the Romanian Marmoniţa, which had been part of the former Cernăuţi rural district established right after the Second World War, Romanians which were arbitrarily inscribed in their passports as "Moldavians". Twelve years later, the compact character of the Romanian ethnic element was still unaltered (200I census figures show a total population of 32,316 inhabitants out of which 29,554 Romanians (91.5\%) and 756 Moldavians (2.34\%), very many Moldavians declaring to be Romanians. As a matter of fact, the non-Romanian population was formed largely of border-guards and their families, as well as of specialists and clerks assigned to work here.

Settlements like Mogoşeşti, Godineşti and Molniţa (Herţa Rajon) or Mămăliga (Noua Suliţă Rajon) bear names that prove the continuity of the Romanian ethnic element. In the Romanian sector, in the riparian Romanian-Ukrainian crossborder area there are three communes (Suharău, Hudeşti and Conceşti) and one town (Darabani) (Heuberger et al., 2010).

The cross-border area between Romania and the Republic of Moldova features the same Romanian ethnic continuity, these nationals making up $90 \%$ and $100 \%$ of the overall local population. The northern end of the area includes the villages of Cuzlău (Romania) and Criva (Rep. of Moldova); in the south there is Galaţi port-city and its counterpart Giurgiuleşti, the latter is the only Danubian port of the Republic of Moldova. The cross-border area numbers fifteen counties: eleven on the lefthandside of the Pruth (Briceni, Edineţ, Râşcani,
Glodeni, Făleşti, Ungheni, Nisporeni, Hânceşti, Leova, Cantemir and Cahul) and four on the righthandside of the River (Botoşani, Iaşi, Vaslui and Galaţi). There are nine border-crossing points located according to the settlement doublets: Siret-Porubne, Rădăuţi Prut-Lipcani, Stânca-Costeşti, Sculeni-Sculeni, Iaşi-Ungheni, Albiţa-Leuşeni, Fălciu-Cantemir, Oancea-Cahul and Galaţi-Giurgiuleşti (Săgeată, 2004-2005) (Table I).

\section{Euro-regions on the Romania / Republic of Moldova frontier line}

As from 1997, three euro-regions: (the Lower Danube, the Upper Pruth and the Siret-PruthDniester), were set up on Romania's eastern frontier based on the system of settlement doublets riparian to the Pruth (Table 2).

The Lower Danube Euro-Region's function in the Pruth area centres around the towns of Galaţi-Cahul-Giurgiuleşti-Reni. Border crossings are Oancea-Cahul (road traffic) and GalaţiGiurgiuleşti-Reni (rail traffic), the only rail connection throughout Romania's euro-region area. Opening several other border crossings between the lefthandside and the righthandside Romanian communities along the River, at the settlement doublets of Măstăcani-Vadul lui Isac (Colibaşi), Tuluceşti-Slobozia Mare or Vădeni-Palcu (Ilieş, 2004) would be welcome (Figure 3).

The Siret-Pruth-Dniester Euro-region, situated in the central part of the cross-border area,

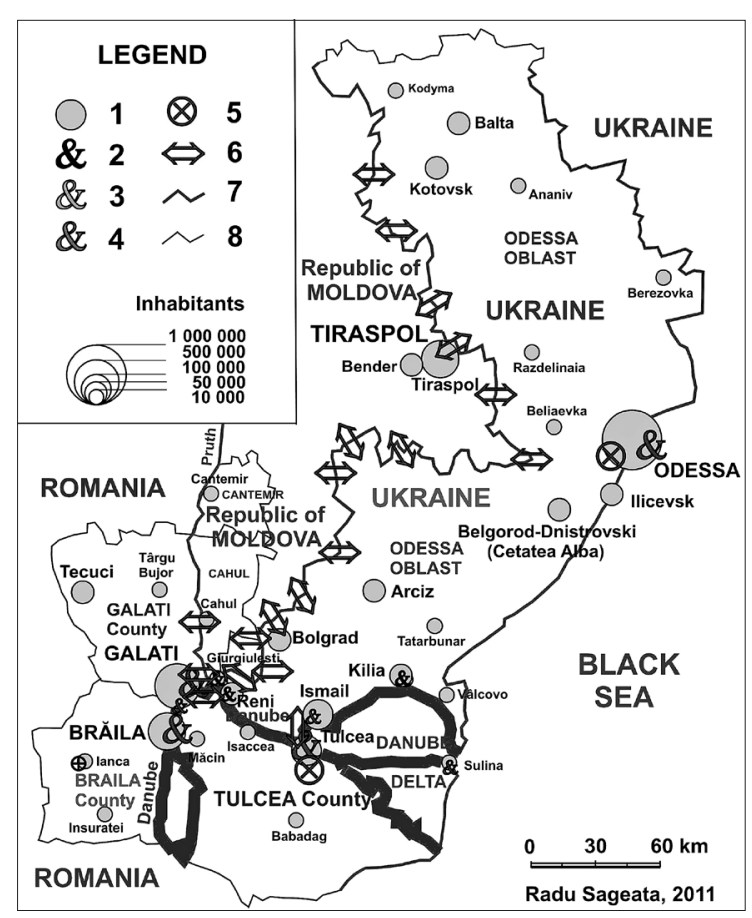

Figure 3. The Lower Danube Euro-region

Polarisation nuclei, 2. River ports, 3. Fluvio-maritime ports,

4. Sea ports, 5. Airport, 6. Cross-border connections,

7. Borderlines, 8. Administrative bounds 
Table 1. Border-crossing points at Romania’s Eastern frontier

\begin{tabular}{|c|c|c|c|c|c|c|}
\hline Customs point & Connections to: & Passage to: & $\begin{array}{l}\text { Transport } \\
\text { regime }\end{array}$ & Traffic regime & County & Euro-region \\
\hline Albița & Leuşeni & Rep. of Moldova & road & International & Vaslui & Siret-Pruth-Dniester \\
\hline Bacău & \multicolumn{2}{|c|}{ International airport } & air flights & International & Bacău & - \\
\hline Fălciu & Stoianovka & Rep. of Moldova & railway & International & Vaslui & Siret-Pruth-Dniester \\
\hline \multirow{2}{*}{ Galați } & \multicolumn{2}{|c|}{ International waters } & port free zone & International & Galați & Lower Danube \\
\hline & Giurgiuleşti & Rep. of Moldova & road railway & International & Galați & Lower Danube \\
\hline \multirow{2}{*}{ Iaşi } & Ungheni & Rep. of Moldova & railway & International & Iaşi & Siret-Pruth-Dniester \\
\hline & \multicolumn{2}{|c|}{ International airport } & air flights & International & laşi & Siret-Pruth-Dniester \\
\hline Izvoarele Sucevei & Sept [Şipot] & Ukraine & road & Small border traffic & Suceava & Upper Pruth \\
\hline Oancea & Cahul & Rep. of Moldova & road & International & Galați & Lower Danube \\
\hline Racovăț & Diakivtzi & Ukraine & road & Small border traffic & Botoşani & Upper Pruth \\
\hline Rădăuți- Prut & Lipcani & Rep. of Moldova & road & International & Botoşani & Upper Pruth \\
\hline Sculeni & Sculeni & Rep. of Moldova & road & International & Iaşi & Siret-Pruth-Dniester \\
\hline Siret & Porubne & Ukraine & road & International & Suceava & Upper Pruth \\
\hline Stânca & Costeşti & Rep. of Moldova & road & International & Botoşani & Upper Pruth \\
\hline Suceava & \multicolumn{2}{|c|}{ International airport } & air flights & International & Suceava & Upper Pruth \\
\hline Sulina & \multicolumn{2}{|c|}{ International waters } & port free zone & International & Tulcea & Lower Danube \\
\hline \multirow{2}{*}{ Tulcea } & \multicolumn{2}{|c|}{ International Airport } & air flights & International & Tulcea & Lower Danube \\
\hline & Ismail and Reni & Ukraine & port & International & Tulcea & Lower Danube \\
\hline Ulma & Rusca & Ukraine & road & Small border traffic & Suceava & Upper Pruth \\
\hline Vicovu de Sus & Krasnoilsk & Ukraine & road & Small border traffic & Suceava & Upper Pruth \\
\hline Vicşani & Vadu Siret & Ukraine & railway & International & Suceava & Upper Pruth \\
\hline
\end{tabular}

Sources: http://www.politiadefrontiera.ro [2011] and Ilieş [2004]

Table 2. The system of euro-regions on the Romania/Republic of Moldova frontier line

\begin{tabular}{|c|c|c|c|c|}
\hline \multirow[t]{2}{*}{$\begin{array}{l}\text { Euro-region / } \\
\text { Foundation year / Area }\end{array}$} & \multirow{2}{*}{$\begin{array}{l}\text { Co-participant } \\
\text { countries } \\
\text { Romania }\end{array}$} & \multicolumn{2}{|c|}{ Administrative-territorial units included } & \multirow{2}{*}{$\begin{array}{l}\text { Urban polarising nuclei } \\
\text { [towns] } \\
\text { Galați, Brăila and Tulcea. }\end{array}$} \\
\hline & & Counties & Galați, Brăila and Tulcea. & \\
\hline \multirow{3}{*}{$\begin{array}{l}\text { Lower Danube } \\
\text { [Dunărea de Jos] } 1997 \\
\text { - 1998, 53,496 km² }\end{array}$} & Rep. of Moldova & Rajons [Districts] * & Cahul, Cantemir. & Cahul. \\
\hline & Ukraine & Region & Odessa. & Odessa. \\
\hline & & Rajon & Reni. & Reni. \\
\hline \multirow{3}{*}{$\begin{array}{l}\text { Upper Pruth [Prutul } \\
\text { Superior] 2000, 42,809 } \\
\mathrm{km}^{2}\end{array}$} & Romania & Counties & Botoşani and Suceava. & Botoşani and Suceava. \\
\hline & Rep of Moldova & Rajons [Districts] * & $\begin{array}{l}\text { Briceni, Edineț, Făleşti, Glodeni, Ocnița } \\
\text { and Râşcani. }\end{array}$ & $\begin{array}{l}\text { Briceni, Edineț, Făleşti, } \\
\text { Glodeni, Ocnița and } \\
\text { Râşcani. }\end{array}$ \\
\hline & Ukraine & Regions & Cernăuți and Ivano-Frankivsk. & $\begin{array}{l}\text { Cernăuți and Ivano- } \\
\text { Frankivsk. }\end{array}$ \\
\hline \multirow[b]{3}{*}{$\begin{array}{l}\text { Siret-Pruth-Dniester } \\
\text { [Siret-Prut-Nistru] } \\
2002,25,560 \mathrm{~km}^{2}\end{array}$} & Romania & & & \\
\hline & Counties & $\begin{array}{l}\text { laşi, Neamț and } \\
\text { Vaslui. }\end{array}$ & Iaşi, Piatra Neamț, Vaslui and Bârlad. & \\
\hline & Rep. of Moldova & Rajons [Districts] * & $\begin{array}{l}\text { Anenii Noi, Basarabeasca, Călăraşi, } \\
\text { Cimişlia, Criuleni, Dubăsari, Floreşti, } \\
\text { Hânceşti, Ialoveni, Leova, Nisporeni, } \\
\text { Orhei, Rezina, Soroca, Străşeni, } \\
\text { Şoldăneşti, Teleneşti, Ungheni and } \\
\text { Chişinău Municipality }\end{array}$ & $\begin{array}{l}\text { Chişinău, Dubăsari, } \\
\text { Floreşti, Hânceşti, Orhei, } \\
\text { Soroca and Ungheni. }\end{array}$ \\
\hline
\end{tabular}




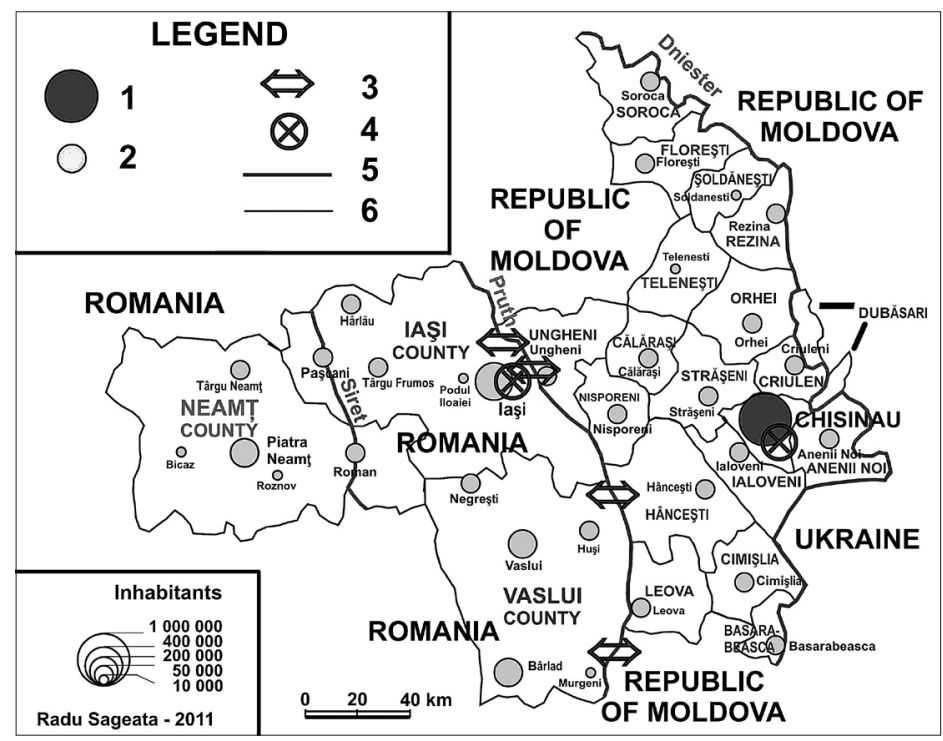

Figure 4. The Siret-Pruth-Dniester Euro-region 1. Capital-city, 2. Polarisation nuclei, 3. Cross-border connections, 4. Airports, 5. Borderlines, 6. Administrative units.

is the only one of the three euro-regions formed of two states: Romania and the Republic of Moldova. About 70 per cent out of the $68 \mathrm{I} .3 \mathrm{~km}$, representing the total length of the frontier between the two states, fall into this euro-region. It includes 22 Pruth riparian administrative units - three in Romania: laşi, Neamţ and Vaslui (Romania); and I9 in Republic of Moldova: Anenii Noi, Basarabeasca, Călăraşi, Cimişlia, Criuleni, Dubăsari, Floreşti, Hânceşti, laloveni, Leova, Nisporeni, Orhei, Rezina, Soroca, Străşeni, Şoldăneşti, Teleneşti, Ungheni and Chişinău Municipality (Rep. of Moldova) (Figure 4), most border crossings passing through laşi-Ungheni points.

The Upper Pruth Euro-Region, largely overlapping the upper basin of the River, encompasses

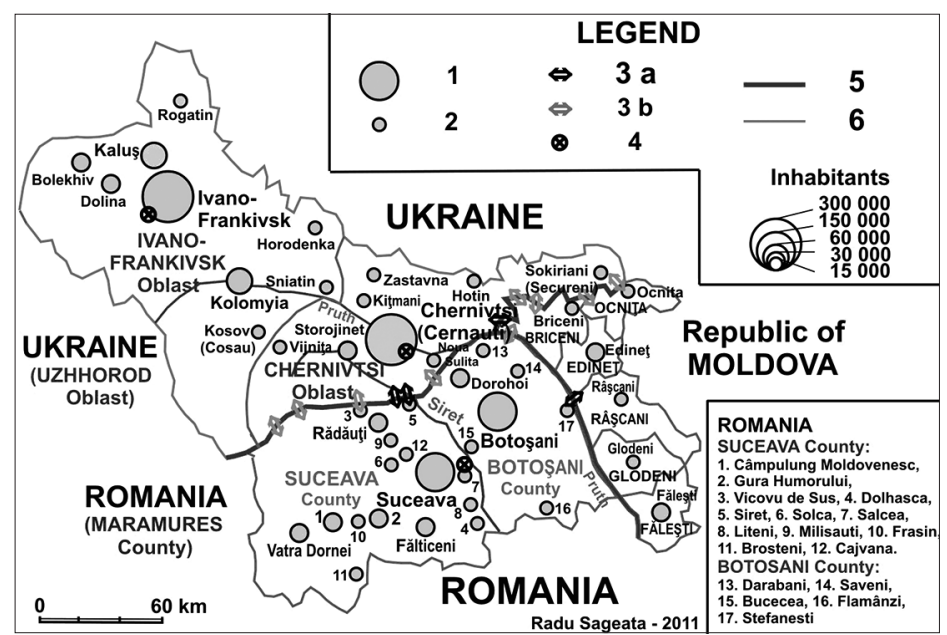

Figure 5. The Upper Pruth Euro-region

Regional polarisation nuclei, 2. Local polarisation nuclei, 3. Cross-border connections: a. International traffic, b. Small border traffic, 4. Airports, 5. Borderlines, 6. Administrative bounds. the countries Botoşani and Suceava (Romania), the districts (rajons): Briceni, Edineţ, Râşcani, Glodeni, Floreşti and Ocniţa (Rep. of Moldova) and the Ukrainian regions Cernăuţi and Ivano-Frankivsk (Figure 5) (Moruzzi, 2004). Despite a good crossborder co-operation potential, the frontier along the Pruth can be crossed only by vehicles, in two points: Rădăuţi Prut-Lipcani and Stânca-Costeşti, other crossings cannot be opened because of the storage-lake at Stânca-Costeşti.

\section{Conclusions}

Extending on the territory of two and three states, the euro-regions discussed in this paper are developed on the EU external frontier, including territories that belong to EU member-states (Romania as of January I, 2007), and territories pertaining to the former Soviet republics (Republic of Moldova and Ukraine) situated on the eastern fringes (2007). As a result, tougher security measures should be implemented at the border, filtering the fluxes of people and materials heading towards the European Union.

The cohesion of these euro-regions relies primarily on their ethnic element, which is compact or majority Romanian, the territories involved having been attached to the Soviet Union in the wake of the Soviet Ultimatum Note (June 28, I940), the direct consequence of the Secret German-Soviet Non-aggression Treaty (RibbentropMolotov). Both banks of the Pruth being strongly populated, the settlement doublets act as relays linking the two settlement systems established against a common historical background.

However, the main link between the three euro-regions occupying either side of the River is ethnical unity and settlement density. Romania's application for EU and NATO membership implied securing its eastern border and controlling migration fluxes. This turned the River Pruth into an axis of integration underlain by the continuity of the ethnic and linguistic element and of habitation on each of its banks. On the other hand, the River has become also an axis of fragmentation imposed by Romania's obligations as NATO and EU member-state to ensure that the Union's border is a secure and stable one. Therefore, cross-border co-operation unfolds specifically on these lines.

\section{References}

Becart, A., Brodaty, S., I998. Cross-border co-operation and local development. Hommes et Terres du Nord I, 35-43. (in French)

Deică, P., I997. Cross-border regions or Euro-regions? Comunicări de Geografie III, 365-368. (in Romanian) 
Engel, C., Rogers, J.-H., I996. How Wide is the border? American Economic Review 86, 5, III2-II25.

Gaunard, M.-F., I998. Territorial border planning in Poland by setting up Euro-regions. Bulletin de l'Association de Géographes Français 76, 4, 429-442. (in French)

Gonin, P., I994. Border regions and endogenous development: New territories in the European Union. Hommes et Terres du Nord 2-3, 6I-70. (in French)

Heuberger, V., Jordan, P., Kahl, Th., Lozovanu, D., 20Io. Ethnic consciousness in the Republic of Moldova in 2004. Atlas Ost- und Südosteuropa / Atlas of Eastern and Southeastern Europe, 2.Io MDi, Österreichischen Akademie den Wissenchaften, Wien, 78 pp. (in German)

Ilieş, Al., 2003. Romania between Millennia. Borders, border areas and border co-operation. Ed. Universităţii din Oradea, Oradea, 236 pp. (in Romanian)

Ilieş, Al., 2004. Romania. Euro-regions, Ed. Universităţii din Oradea, Oradea, 2I8 pp. (in Romanian)

Kalmustskaia, E., 2004. Demographic and Socioeconomic Relations in the Chernivtsi border region. Geographica Timisensis XIII, 2, I09-II3. (in French)

Mâtcu, M., Sochircă, V, 2002. Human Geography in the Republic of Moldova. Ed. Arc, Chişinău, I99 pp. (in Romanian)

Moruzi, O., 2004. The Upper Pruth Euro-region. Modern cross-border co-operation tools. Geographica Timisensis XIII, 2, I03-I08. (in French)

Neguţ, S., I998. The Euro-regions. Revue Roumaine de Géographie 42, 75-85. (in French)

Popa, N., 2004. Borders and border regions in Romania: between regions, cultures and functions. Geographica Timisensis XIII, 2, 79-IO2. (in French)

Popescu, I., 2004. Romanians in the historical region of Hertza. Dacoromania I7, I2-I5. (in Romanian)

Reynauld, A., I98I. Society, space and justice. Presses Universitaires de France, Paris, 263 pp. (in French)

Rougier, H. I999. From the notion of region to the Euro-region. Bulletin de l'Association de Géographes Français 4, 394-396. (in French)

Rus, D. 1997. Territories inhabited by Romanians living abroad. Ed. Sigma Plus, Deva, 248 pp. (in Romanian)

Săgeată, R., 2004. The Role of the Doublet settlements in the Euro-Regions Structure - A Case
Study: The Romanian-Bulgarian Border Space in the Danube Sector. in: Ilieş, Al. \& Wendt, J. (eds.): Poland and Romania Enlargement of European Union and NATO, International Geographical Union, Carta Blanca, Warsaw, I25-I3I. Săgeată, R., 2004-2005. Systems of settlements and cross-border co-operation in the Pruth Basin. Studii şi Cercetări de Geografie LI-LII, 65-78. (in Romanian)

Săgeată, R., 2005. Cross-border areas and Euroregions in the globalisation process. GeoPolitica, Revistă de Geografie Politică, Geopolitică şi Geostrategie III, I3, 67-74. (in Romanian)

Săgeată, R., 20o6a. The Romanian-Romanian border. An appeal to memory, GeoPolitica, Revistă de Geografie Politică, Geopolitică şi Geostrategie IV, I6-I7, I65-I72. (in Romanian)

Săgeată, R., 2006b. Settlements. Political-administrative decisions and organisation of the geographical space. Ed. Universităţii Naţionale de Apărare Carol I \& Ed. Top Form, Bucharest, 396 pp. (in Romanian)

Săgeată, R., 2008. The regions of Europe. Methodology of regional analysis. Ed. Fundaţiei „România de Mâine”, Bucharest. (in Romanian)

Săgeată, R., 2009. Romania. A Geopolitical Outline. in: Heller, W., Arambaşa, M-N. (eds.): Am östlichen Rand der Europäischen Union, Potsdamer Geographische Forschungen 28, Universität Potsdam, 45-58.

Săgeată, R., Dumitrescu, B., Damian, N., 2010. Cross-Border Cooperation in the DanubeLined Romanian/Bulgarian Border Space. Geographical Considerations. Geographica Pannonica I4, 2, 67-75.

Seguy, R., I998. The Euro-region, an economic space under construction? Hommes et Terres $d u$ Nord I, I7I-I75. (in French)

Simileanu, V., Săgeată, R., 2009. Romania and its geopolicies. Ed. Top Form, Bucharest, 466 pp. (in Romanian)

Stamate, Gr., I997. The state border of Romania. Ed. Militară, Bucureşti, 359 pp. (in Romanian)

Ungureanu, Al., Groza, O., Muntele, I., 2002. The province of Moldavia - Romania. Population, labour force settlements under transition. Ed. Corson, Iaşi, 243 pp. (in Romanian)

Wackermann, G. I990. Cultural exchanges in cross-border areas. Bulletin de l'Association de Géographes Français 5, 347-355. (in French)

Wackermann, G. I99I. Societies and cross-border territorial planning with disparities. Revue Géographique de l'Est XXXI, 2, 89-98. (in French) 